\title{
リニアモータ駆動·水静圧案内テーブルの開発* （作動流体に混入した気泡がテーブルの動特性に及ぼす影響）
}

\author{
岡畑 豪*1

\begin{abstract}
Development of a Linear-Motor-Driven Table with Hydrostatic Water Bearings (Influence of Air Bubble Contained in Hydraulic Fluid on Dynamic Behavior of the Table)
\end{abstract}

\author{
Go OKAHATA*1, Akinori YUI, Shigeki OKUYAMA, Hisashi KOBAYASHI and A. H. Slocum \\ $1^{1 *}$ Department of Mechanical Systems Engineering, National Defense Academy, \\ Hashirimizu 1-10-20, Yokosuka-shi, Kanagawa, 239-8686 Japan
}

A linear-motor-driven table sustained by constant-flow hydrostatic water bearings has been developed. The table, which is supported by single-sided recess type bearings, is preloaded by its weight and the attractive force arising from permanent magnets of the linear-motor. Due to periodic change of the magnet polarity, the amplitude of the attractive force changes according to the table position. As a result, pitching motion of the table is generated during the table-feed motion. This paper investigates the influence of air bubble contained in hydraulic fluid on static stiffness and dynamic behavior of the table. Damping ratio and natural frequency of the table become smaller under larger volume of containing air. When natural frequency of the table pitching motion coincides with the frequency of the attractive-force change, the largest pitching motion is observed.

Key Words: Linear Motor, Hydrostatic Water Bearing, Dynamic Behavior, Pitching, Damping Ratio, Air Bubble

\section{1. 緒言}

近年 , 精密機械部品や光学口電子部品の微細化口高精度化に伴い，これらを加工する工作機械を構成するテーブ ルの運動精度向上への要求が高まっている(1) . また , 地球環境保全のため, 工作機械の脱鉱油化も求められてい $ろ^{(2)}$. 特に, 半導体部品の加工においては, 加工機械と加工工程の脱鉱油化が重要である ${ }^{(3)}$.

テーブル運動の高精度化を目的とした空気静圧案内(4),(5) や油静圧案内(6),(7) $の$ 研究や少の使用例は多い.なかで も空気静圧軸受は, クリーンな環境て使用でき, 超精密計測機器や加工力の小さい超精密工作機械などに多用さ れているが，高い支持岡性を得るのか灘しく，一般の工作機械にはほとんど用いられない，㚇のため，作動流体 に純水を用いた静圧軸受の実現か赇められている。しかし,水を作動流体に用いた静圧軸受に関する研究口開発例 は少ない . 例えば, 長島らは対向式水静圧テーブルの負荷容量や静岡性に関する研究を行っている ${ }^{\left({ }^{8)}\right.}$. また , 磯 部らは回転主軸に水静圧軸受を採用した大口径ウエハ研削盤を開発している(9) .しかし，これらの軸受はいずれ も定圧力方式を採用していることから , オリフィス絞りなどの狭窄部にバクテリアや錆あるいは微細な粉鹿か詰 まる恐れがある．

そこで筆者らは，図 1 に示す片側リセス方式の水静圧軸受を備えたリニアモータ駆動テーブルを試作した ${ }^{(10),(11)}$. 本システムは以下の特長を有している . (1)定流量方式の静圧軸受を採用しており，絞りがないのでバクテリアな

\footnotetext{
* 原稿受付 2013 年 8 月 21 日

${ }^{* 1}$ 正員，防衛大学校機械システム工学科（†239-8686 神奈川県横須賀市走水 1-10-20）

*2 防衛大学校名誉教授（广239-0822 神奈川県横須賀市浦賀 5-25-6）

*3 岡本工作機械（广379-0135 群馬県安中市郷原 2993）

*4 マサチューセッツ工科大学（77, Massachusetts Ave., Cambridge, MA, 02139, USA）

E-mail: okahata@nda.ac.jp
} 


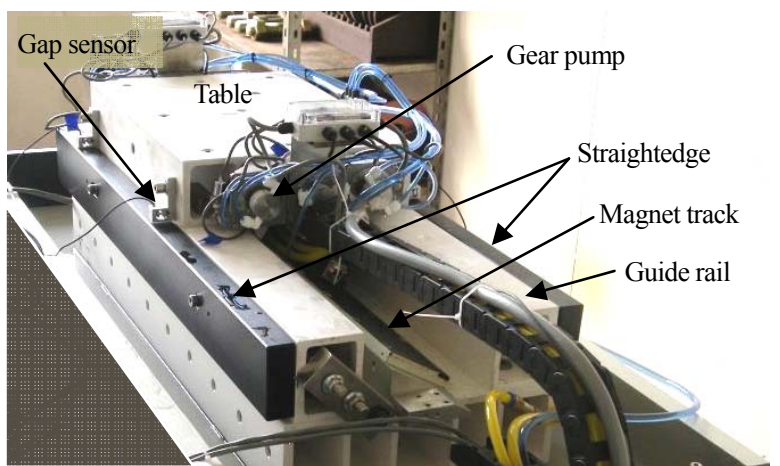

Fig.1 Appearance of the developed table system equipped with hydrostatic water bearings

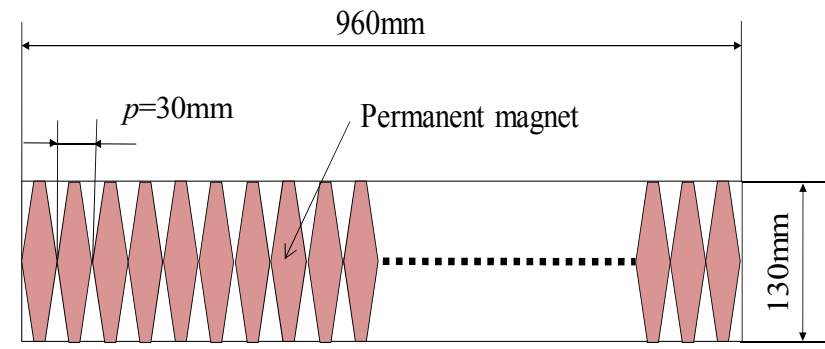

Fig.3 Schematic view of the magnet track of the linear-motor

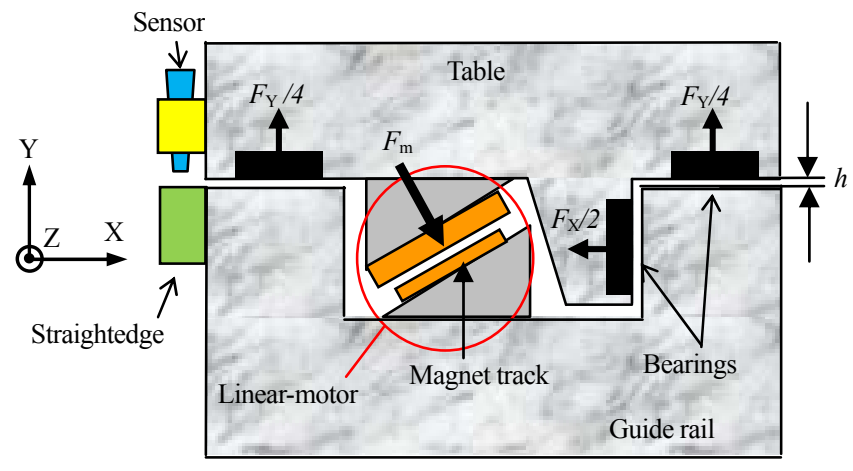

Fig.2 Cross sectional image of the table system

Table 1 Specification of the developed table system

\begin{tabular}{lr|l}
\hline Table size & {$[\mathrm{mm}]$} & $480 \times 350($ length $\times$ width) \\
\hline Table stroke $\quad[\mathrm{mm}]$ & 400 \\
\hline Table acceleration $\left[\mathrm{m} / \mathrm{s}^{2}\right]$ & 10 \\
\hline Material of table components & Alumina ceramics \\
\hline Bearing & Single-sided recess type \\
\hline Hydraulic fluid & Pure water \\
\hline Constant flow pump & Micro gear pump \\
\hline Total attraction force $F_{\mathrm{m}}[\mathrm{N}]$ & 3480 \\
\hline
\end{tabular}

どか詰まる心配がない . (2)片側リセス方式の軸受とリニアモータの採用により，構造が単純て組み立てや保守が 容易である . (3)コア付きリニアモータの強い磁気吸引力を利用してプリロードを付与することによって , テーブ ルの支持岡性を高めている . (4)水を低流量で使用するため，消費電力や騒音が小さい． (5)水は，石油系作動油に 比べて低粘度かつ体積弾性率が大きいため, システムの高岡性化に適し，かつ発熱を抑制できる .66脱鉱油化を 実現した地球環境にやさしいシステムである .

一方，採用した片側リセス方式の場合には，テーブルのピッチングや上下方向変位（ヒービング）を機械的に 拘束することができないという問題がある . 光こで上記のように , リニアモータの吸引力をテーブル運動の拘束 と軸受の高岡性化のために使用している．しかし，リニアモータの永久磁石列は， S 極と N 極の磁石か交互に配 置されているため, テーブルの移動に伴ってコアに働く磁気吸引力が周期的に変動し，ピッチングを誘発するな どの欠点がある . また, 定流量ポンプの流量 $Q$ は $1 \mathrm{~mL} / \mathrm{s}$ 程度と非常に小さいため, ポンプから静圧軸受に至る配 管中に気泡が混入すると光の排除が難しく , テーブルの動特性に悪影響を及ぼす恐れがある .

乥こで本研究では，筆者らが開発したテーブルシステムについて，作動流体中に混入した気泡や配管内の空気 溜りがテーブルの支持岡性や動特性に及ぼす影響を検討する．

\section{2. テーブルの基本仕様と構造}

本テーブルシステムでは, 図 2 に示すように 30に傾斜配置したリニアモータ (ファナック製 , L $1500 B 1 / 4 i S$ ) によって Z 軸方向にテーブルを駆動するとともに, 弚の磁気吸引力によって-Y 及び+X 方向の拘束力を付与して いる.リニアモータの永久磁石とコアの磁気隙間 $s$ は $1.1 \mathrm{~mm}$ に設定しており，この時の全磁気吸引力 $F_{\mathrm{m}}$ は $3480 \mathrm{~N}$ である ${ }^{(11)}$. 従って , - Y 軸方向にはテーブルの自重 $(575 \mathrm{~N})$ と $F_{\mathrm{m}} \square \cos 30^{\circ}=3014 \mathrm{~N}$ の和，つまり $3589 \mathrm{~N}$ のプリロー ドが，X軸方向には $F_{\mathrm{m}}$ 少 $\sin 30^{\circ}=1740 \mathrm{~N}$ のプリロードが付与されている . テーブルには , $\mathrm{Y}$ 軸方向に 4 個 , $\mathrm{X}$ 軸方 向に 2 個の静圧軸受パッドを配し，これらのプリロードを支えている.テーブルの基本的な仕樣を表 1 に示す．

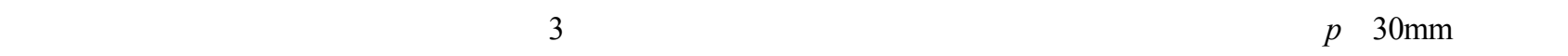




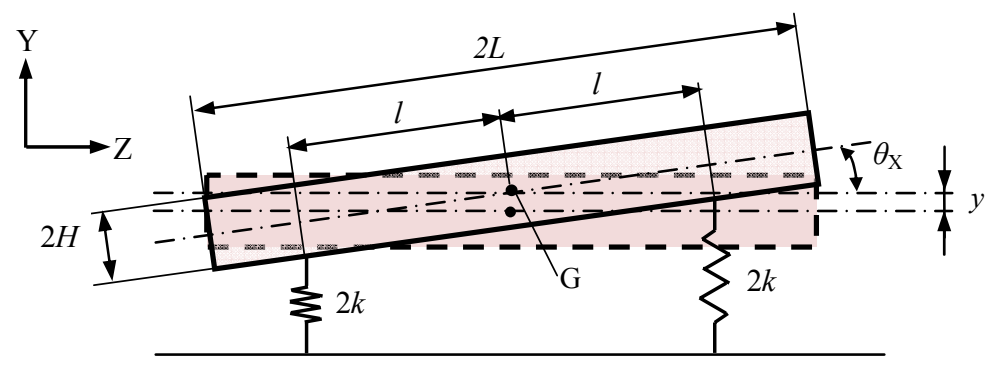

Fig.4 Pitching and heaving motion of the table

隔に配置されている．したがって , テーブルがZ 軸方向に運動する際にリニアモータのコアが受ける力は , この ピッチて変化する .すなわち, テーブルの送り速度を $v(\mathrm{~mm} / \mathrm{s})$ とすると, コアに加わる吸引力は周波数 $f=v / p$ $(\mathrm{Hz})$ で周期的に変動する.

\section{3. テーブルの固有振動数の試算}

水静圧軸受は非常に高いダンピング特性を有するが(10)，先ずテーブルの固有振動数について議論するため, テ 一ブルを質量 $M$, 長さ $2 L$ の均質な岡体と仮定し , 図 4 に示す簡単な 2 自由度系の振動モデルを考える . 4 個の静 圧軸受のばね定数 $k$ は等しいものとすると, $\mathrm{Y}$ 軸方向のテーブル支持岡性は $4 k$ となる .ガイドレールに対するテ 一ブルのY 軸方向の相対変位 (ヒービング) 量を $y$ とすると , ヒービングモードの運動方程式は次式で表わされ る.

$$
M \ddot{y}+4 k y=0
$$

このとき , ヒービングモードの固有振動数 $\omega_{\mathrm{h}}(\mathrm{Hz})$ は , 次式で与えられる .

$$
\omega_{\mathrm{h}}=\frac{1}{2 \pi} \sqrt{\frac{4 k}{M}}
$$

また , テーブルの重心 $\mathrm{G}$ から左右の静圧軸受（リセス中心）までの水平距離を $l$ とし , テーブルの $\mathrm{X}$ 軸回りの慣 性モーメントを $I_{\mathrm{X}}$, ピッチング角を $\theta_{\mathrm{X}}$ とすると，ピッチングモードの運動方程式は $\theta_{\mathrm{x}}$ が小さい場合に次式で与 えられる．

$$
I_{\mathrm{X}} \ddot{\theta}_{\mathrm{X}}+4 k l^{2} \theta_{\mathrm{X}}=0
$$

従って , ピッチングモードの固有振動数 $\omega_{\mathrm{p}}(\mathrm{Hz})$ は , 次式で与えられる .

$$
\omega_{\mathrm{p}}=\frac{1}{2 \pi} \sqrt{\frac{3}{M}\left(\frac{l^{2}}{L^{2}+H^{2}}\right) 4 k}
$$

ここで, $H$ はリニアモータのコイルやコア部などを含むテーブルの等価高さである. 表 2 に示す標準実験条件 (テ 一ブル静岡性 $4 k=700 \mathrm{~N} / \mu \mathrm{m}$ ，スライダ質量 $M=58.7 \mathrm{~kg}, L=240 \mathrm{~mm}, H=60 \mathrm{~mm}, l=160 \mathrm{~mm}$ ) を式 (2)，式 (4) に代入して固有振動数を求めると, 乥れ光れ $\omega_{\mathrm{h}}=550 \mathrm{~Hz}, \omega_{\mathrm{p}}=616 \mathrm{~Hz}$ となる .

以上の試算では，作動流体の粘性による減衰力や使用した定流量ポンプの性能は考慮していないため，次にこ れらの影響について考える . 例えば，本テーブルシステムに用いた静圧パッド (長方形パッド) と等価な正方形 パッド 4 個によって，質量 $M=58.7 \mathrm{~kg}$ のテーブルが，流量 $Q=1 \mathrm{~mL} / \mathrm{s}$ ，軸受すきま $h=16 \mu \mathrm{m}$ で支持されている時， ヒービングモードにおける粘性減衰係数 $B_{\zeta}$ は $78 \mathrm{MN} \square \mathrm{s} / \mathrm{m}$ であり ${ }^{(10)}$, 減衰比 $\zeta_{\mathrm{h}}$ は 192 になる . ある質量がばねと ダンパで支持された系は, 二次遅れ系と呼ばれ，弚のインディシャル応答 $y(t)$ は, 次のようになることが知られ ている。

$$
y(t)=1-\frac{\left(\zeta_{\mathrm{h}}+\sqrt{\zeta_{\mathrm{h}}{ }^{2}-1}\right)}{2 \sqrt{\zeta_{\mathrm{h}}{ }^{2}-1}} \exp \left[\left(-\zeta_{\mathrm{h}}+\sqrt{\zeta_{\mathrm{h}}{ }^{2}-1}\right) \omega_{\mathrm{h}} t\right]+\frac{\left(\zeta_{\mathrm{h}}-\sqrt{\zeta_{\mathrm{h}}{ }^{2}-1}\right)}{2 \sqrt{\zeta_{\mathrm{h}}{ }^{2}-1}} \exp \left[\left(-\zeta_{\mathrm{h}}-\sqrt{\zeta_{\mathrm{h}}{ }^{2}-1}\right) \omega_{\mathrm{h}} t\right]
$$




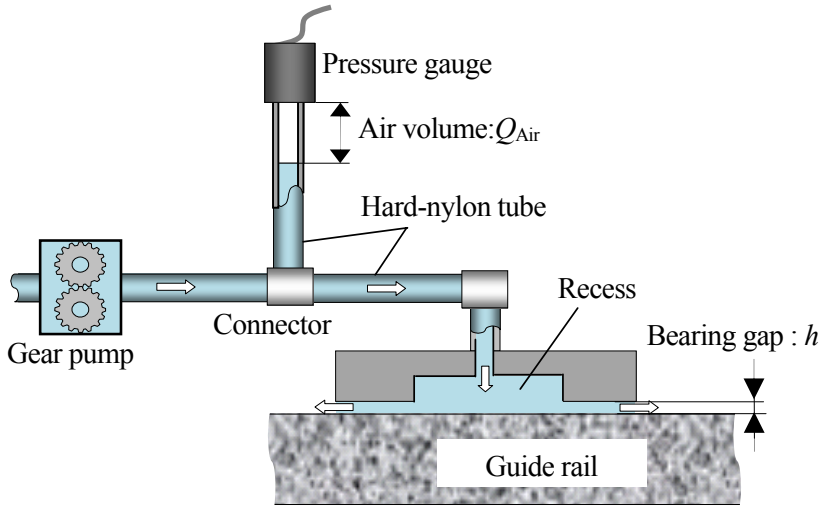

Fig.5 Schematic image of the water supply system with air containing tube
Table 2 Basic conditions for the experiments

\begin{tabular}{lcr|c}
\hline Water flow rate & $Q$ & {$[\mathrm{~mL} / \mathrm{s}]$} & $1.0 /$ recess \\
\hline Table speed & $v$ & {$[\mathrm{~mm} / \mathrm{s}]$} & $0-55$ \\
\hline Bearing gap & $h$ & {$[\mu \mathrm{m}]$} & 16 \\
\hline Static stiffness of the table & $4 k$ & {$[\mathrm{~N} / \mu \mathrm{m}]$} & 700 \\
\hline \multicolumn{1}{l}{ Table mass } & $M$ & {$[\mathrm{~kg}]$} & 58.7 \\
\hline Table length & $2 L$ & {$[\mathrm{~mm}]$} & 480 \\
\hline Bearing position from the center & $l$ & {$[\mathrm{~mm}]$} & 160 \\
\hline Removing load & & {$[\mathrm{N}]$} & 980 \\
\hline Containing air volume & $Q_{\text {Air }}$ & {$[\mathrm{NmL} / \mathrm{recess}]$} & $0-7.95$ \\
\hline
\end{tabular}

ただし，上記のような非常に高し隇衰比 $\zeta_{\mathrm{h}}$ を有する場合，

$$
\zeta_{\mathrm{h}}-\sqrt{\zeta_{\mathrm{h}}{ }^{2}-1} \fallingdotseq \frac{1}{2 \zeta_{\mathrm{h}}}
$$

となるから，このような二次遅れ系のインディシャル応答は，次式で近似できる．

$$
y(t) \fallingdotseq 1-\exp \left(-\frac{\omega_{\mathrm{h}}}{2 \zeta_{\mathrm{h}}} t\right)=1-\exp \left(-\frac{4 k}{B_{\zeta}} t\right)
$$

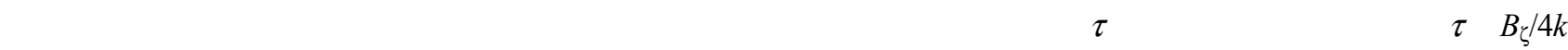
$=78(\mathrm{MN} \square \mathrm{s} / \mathrm{m}) / 700(\mathrm{MN} / \mathrm{m})=0.11 \mathrm{~s}$ か得られる.従って,$y(t)$ が $95 \%$ に達するのに必要な時間 $(3 \tau)$ は約 $0.33 \mathrm{~s}$ となる.つまり本テーブルシステムは, 前述のヒービング軍動の固有振動数 $\left(\omega_{\mathrm{h}}=550 \mathrm{~Hz}\right)$ には全く追随できず， 安定な系であるといえる

次に, 定流量ポンプの流量の観点から振動への追随能力を考えてみる.軸方向に配置した一個の静圧軸受か汥 えるスライダの表面積は $240 \times 84\left(\mathrm{~mm}^{2}\right)$ であり，また表 2 より，各定流量ポンプの設定流量 $Q$ は $1.0 \mathrm{~mL} / \mathrm{s}$ であ るから，例えばテーブルを $1 \mu \mathrm{m}$ 浮き上がらせるのに必要な水を供給するのに $0.02 \mathrm{~s}$ を要する. この值は，急激な 除荷によってテーブルが $1 \mu \mathrm{m}$ 浮き上がるのに要する時間 $(3 \tau=0.33 \mathrm{~s})$ よりも十分小さい.つまり，このような ごく微小なステップ状の運動には $Q=1.0 \mathrm{~mL} / \mathrm{s}$ て追随可能である.しかし, 数十 $\mu \mathrm{m}$ 単位の大きなステップ状の運 動には追随できない．

本テーブルシステムが, 数 $\mathrm{Hz}$ を超える高い周波数の振動に追随できないのは, 水か粘性抵抗を有することと, 非圧縮生流体として取り扱えるものであることに起因しているが, リセス内や配管中に気泡が混入したり空気溜 りができたりすると，水は体積弹性率の小さな圧縮性流体として作用し ${ }^{(12),(13)}$, テーブルシステムの隇衰性能や， 運動の安定性に悪影響を及ぼすと考えられる，乥こで次節では，配管中に空気を封入した場合における，本シス テムのステップ応答およびテーブルの送り運動時のピッチングについて実験的に検討する．

\section{4. テーブルの動特性の測定方法と条件}

図 5 は, 歯車ポンプからリセスに至る作動流体の供給回路の概略図である . 各静圧軸受には, DC サーボモ一 タを組み込んだ小型歯車ポンプ (IDEX Corp., GA-X21) によって定流量の純水を供給し，弚の流量をコリオリ式 流量計 (キーエンス製 FD-SS02) にてモニタする . 純水の流量は非常に小さいので, 歯車ポンプとリセスの間に おける圧力損失はないものと考え, リセス内圧力を配管中に設置したダイヤフラム式圧力計 (共和電業製 PGM-10KC) にてモニタする . 本実験では, 配管内の空気体積 $Q_{\text {Air }}$ の影響を調べるため , 歯車ポンプとリセスの 間に内径 $4 \mathrm{~mm}$ の透明な硬質ナイロンチューブ(Pisco 製 NA0640) を挿入し， $Q_{\text {Air }}=0 \sim 7.95 \mathrm{NmL}$ の空気を封入する . なお $Q_{\text {Air }}$ は , 透明な硬質ナイロンチューブの空気部分の長さを測定し , これにチューブの断面積を掛けることに よって算出した体積と，測定した配管内の圧力をもとに，大気圧中（101,325Pa）での体積に換算した值である．

ヒービングモードの応答は, テーブルの中央に積載した荷重 $(980 \mathrm{~N})$ を小型クレーンを用いて瞬時に除荷した 


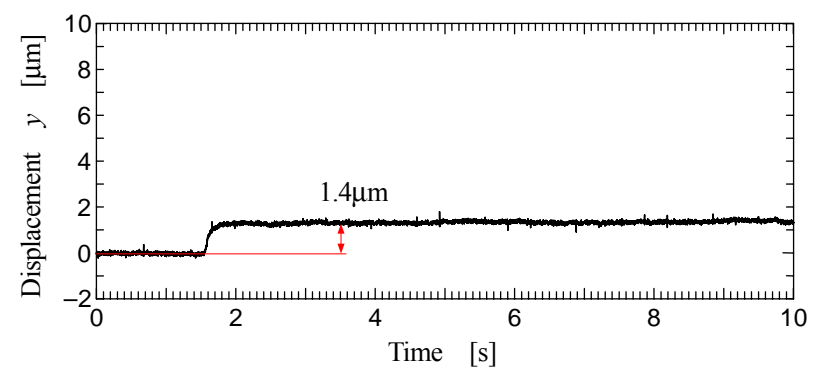

(a) $Q_{\text {Air }}=0 \mathrm{NmL}$

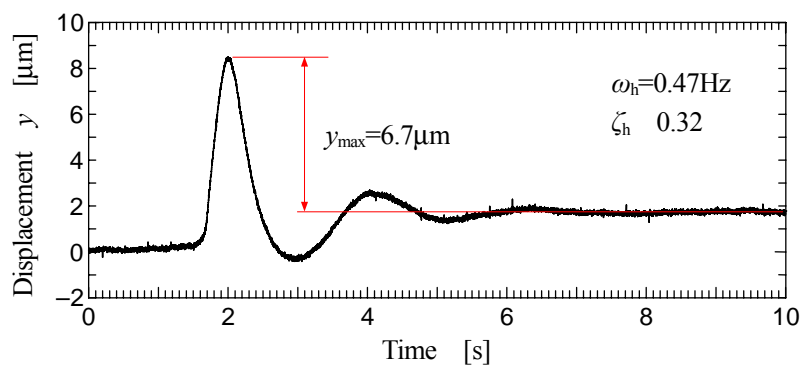

(b) $Q_{\text {Air }}=7.95 \mathrm{NmL}$

Fig.6 Effect of containing air volume, $Q_{\text {Air }}$, on displacement, $y$, when $980 \mathrm{~N}-$ load is suddenly removed from the table

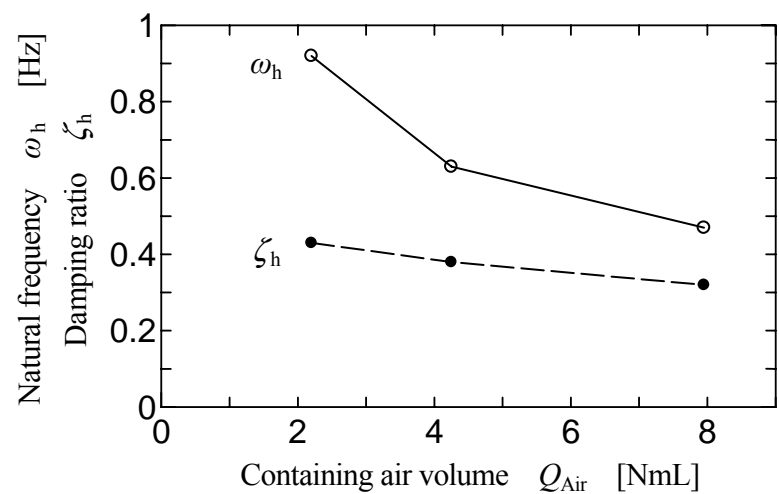

Fig.7 Effect of $Q_{\text {Air }}$ on natural frequency, $\omega_{\mathrm{h}}$, and damping ratio, $\zeta_{\mathrm{h}}$, under heaving mode vibration when $980 \mathrm{~N}-$ load is suddenly removed from the table

時の, 直定規上面を基準としたテーブルの垂直変位 $y$ を, テーブルの対角上に取り付けた 2 つの渦電流式変位計 (Lion Precision 製 U5-18C 130, 応答周波数 $1 \mathrm{kHz}$ ) で測定し, 出力の平均值の推移から求める.またピッチング モードの応答は, テーブルの左端から $80 \mathrm{~mm}$ の位置に積載した偏荷重を瞬時に除荷した際における, テーブル両 端の垂直変位の差を 2 個の渦電流式変位計で測定し, これを両プローブの設置間隔 $(2 L)$ て除して求める.

一方 , テーブルの Z 軸方向の運動時における X 軸周りの姿勢変化（ピッチング角 $\theta_{\mathrm{X}}$ ）は, テーブルの左右端 に設置した , 2 個の電気マイクロメータ (TESA 製 GT31, 応答周波数 $25 \mathrm{~Hz}$ ) で, 直定規上面 (Precitech 製, 真直 度 $\pm 0.36 \mu \mathrm{m} / 1000 \mathrm{~mm})$ をトレースし, 両者の出力差を $2 L$ て除して求める.

\section{5. 実 験 結 果}

\section{$5 \square 1$ テーブル停止時のステップ応答( ヒービングモード )}

図 6 に, テーブル中央部に積載した荷重 $(980 \mathrm{~N})$ を, 小型クレーンて瞬時に除荷した際の垂直変位 $y$ の時間変

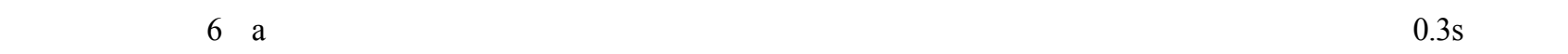
定常状態に落ち着いており，3 節で試算した $3 \tau=0.33 \mathrm{~s}$ に近い. 本テーブルシステムでは定流量ポンプの流量が 非常に小さいことから，現状では一度混入した気泡を排除することは容易でないが，この結果は, 封入空気量ゼ 口の条件がほぼ実現されていることを示している．なお，定流量ポンプによる水の供給によって，テーブルをさ らに $1.4 \mu \mathrm{m}$ 浮かせるのに必要な時間は, 3 節での試算結果から $1.4 \mu \mathrm{m} \times 0.02 \mathrm{~s} / \mu \mathrm{m}=0.028 \mathrm{~s}$ であり, 設定した流量 $(Q$ $=1 \mathrm{~mL} / \mathrm{s}$ ) で上記の応答速度（約 $0.3 \mathrm{~s} ）$ に十分追随できる．

一方，図 6 (b) に示した $Q_{\text {Air }}=7.95 \mathrm{NmL}$ の場合には減衰振動しており，テーブルの最大変位 $y_{\max }$ は $6.7 \mu \mathrm{m}$ に達 する.これは , 封入した空気か除荷に伴って急膨張し，ばねのように作用したことを示している.図 6 (b) から 算出した対数減衰率より求めた減衰比 $\zeta_{\mathrm{h}}$ は 0.32 程度であり ,この $\zeta_{\mathrm{h}}$ と同図の振動周期から算出したヒービングモ 一ドの固有振動数 $\omega_{\mathrm{h}}$ は約 $0.47 \mathrm{~Hz}$ になる このときの支持岡性 $4 \mathrm{k}^{\prime}$ を式(2) を用いて逆算してみると $4 \mathrm{k}^{\prime}=510 \times 10^{-6}$ $\mathrm{N} / \mu \mathrm{m}$ となり，7.95NmL の空気の封入によって動的な条件下での支持岡性が極度に低下したことがわかる．

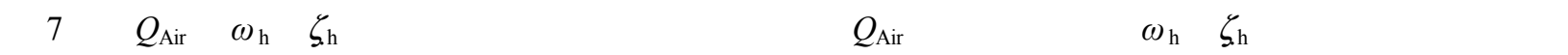
$Q_{\text {Air }}$ を $2.2 \mathrm{NmL}$ に減らしても固有振動数は $0.92 \mathrm{~Hz}$ 程度であり $, 4 \mathrm{k}^{\prime} を 1,960 \times 10^{-6} \mathrm{~N} / \mu \mathrm{m}$ に増加させるに過ぎない .つ 


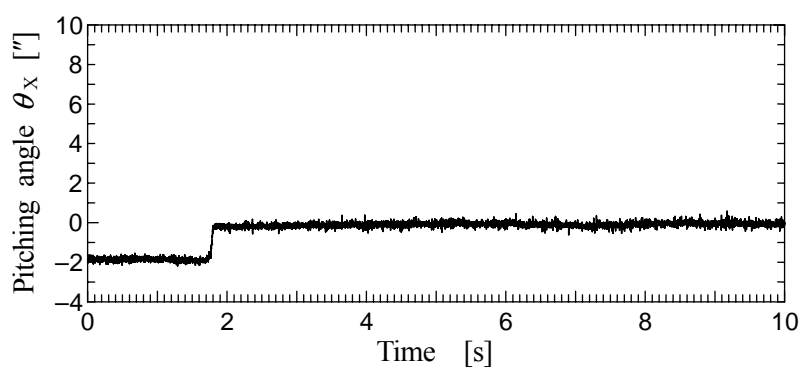

(a) $Q_{\text {air }}=0 \mathrm{NmL}$

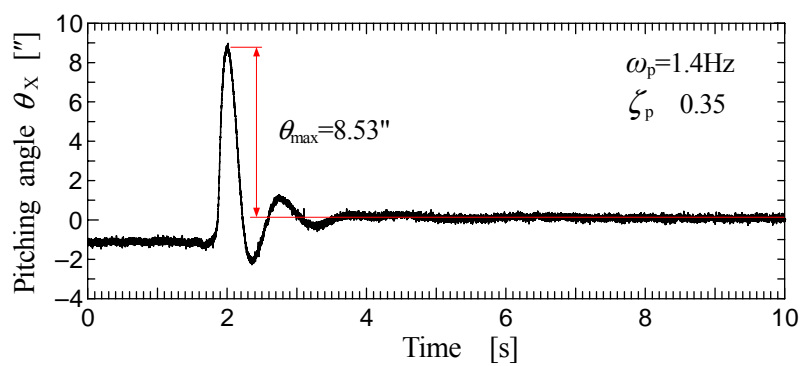

(b) $Q_{\text {air }}=7.07 \mathrm{NmL}$

Fig.8 Effect of $Q_{\text {Air }}$ on pitching angle, $\theta_{\mathrm{X}}$, when eccentric load of $980 \mathrm{~N}$ is suddenly removed from the table

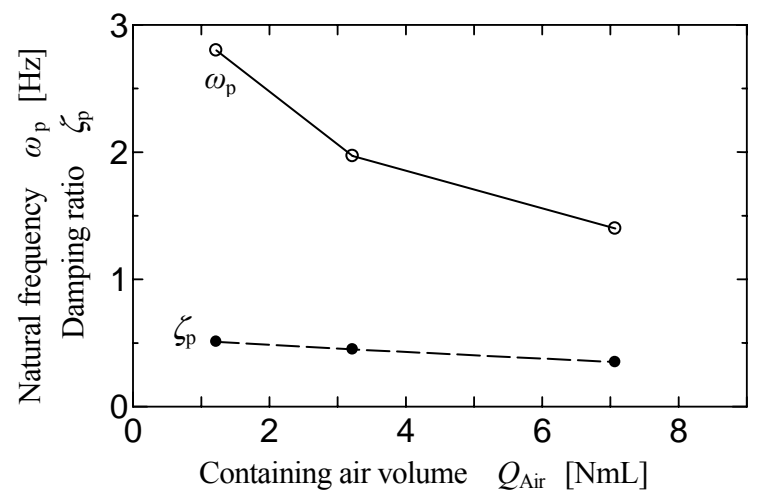

Fig.9 Effect of $Q_{\text {Air }}$ on natural frequency, $\omega_{\mathrm{p}}$, and dumping ratio, $\zeta_{\mathrm{p}}$, under pitching mode vibration when eccentric load of $980 \mathrm{~N}$ is suddenly removed from the table

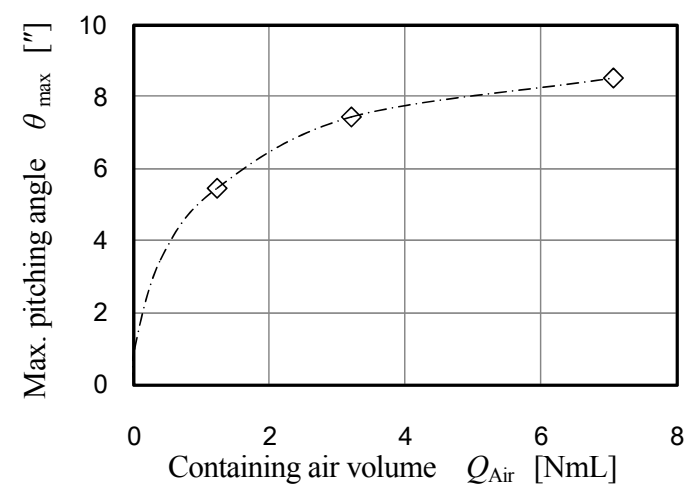

Fig.10 Effect of $Q_{\text {Air }}$ on the maximum pitching angle, $\theta_{\max }$

まり， $Q_{\text {Air }}=0 \mathrm{NmL}$ での支持岡性の約 1/357,000 に低下する . このように，定流量ポンプからリセスに至る流体中 への空気の混入は, 弚れか微量であってもテーブルの動的な条件下での支持岡性を著しく低下させるばかりでな く, テーブルの運動を不安定にさせる .このことから , システムの構築に当たっては, 気泡の混入を防ぐととも に , 混入した配管中の気泡や空気溜りを自律的に排除できる機能を付加することが不可欠である .

\section{$5 \square 2$ テーブル停止時の振動特性( ピッチングモード )}

図 8 は, テーブルに積載した $980 \mathrm{~N}$ の偏荷重を瞬時に除荷した際のピッチング角 $\theta_{\mathrm{x}}$ の変化を示す . 図 8 (a) に 示した $Q_{\mathrm{Air}}=0 \mathrm{NmL}$ の場合には, 静的な姿勢変化がステップ状に発生するだけで振動は起こらない . これに対し 図 8 (b) に示した $Q_{\text {Air }}=7.07 \mathrm{NmL}$ の場合には, 最大ピッチング角 $\theta_{\max }=8.53$ "であり，ピッチングの減衰に約 $3 \mathrm{~s}$ を要している.

図 9 に $Q_{\text {Air }}$ がピッチングモードの固有振動数 $\omega_{\mathrm{p}}$ と減衰比 $\zeta_{\mathrm{p}}$ に及ぼす影響を示す.$Q_{\mathrm{Air}}$ の増加に伴って $\omega_{\mathrm{p}}$ と $\zeta_{\mathrm{p}}$ は小さくなっており，テーブルは外力 (モーメント荷重) の影響を受けやすくなるといえる．また図 10 は， $Q_{\text {Air }}$ と $\theta_{\max }$ の関係を示したもので, わずかでも気泡が混入すると $\theta_{\max }$ は急拡大することから, 気泡の混入を避けるこ とは非常に重要といえる.

\section{$5 \square 3$ テーブルの送り速度と封入空気量がピッチング角に及ぼす影響}

図 11 は, $Q_{\mathrm{Air}}=0 \mathrm{NmL}$ においてテーブルを $\mathrm{Z}$ 軸方向に低速送り $(v=1.67 \mathrm{~mm} / \mathrm{s})$ した時のピッチング角 $\theta_{\mathrm{x}}$ の変 化を示している. テーブルは, 送り運動に伴って半振幅 $\theta_{\mathrm{amp}}=0.2 "$ のピッチングを繰り返している . また振動の ピッチ $p^{\prime}=30 \mathrm{~mm}$ は, 図 3 に示した永久磁石列の配列ピッチ $p$ に一致している . 図は省略するが, 送り速度 $v を$ 変化させた場合, 振動の周波数は $v$ に比例するものの $p^{\prime}$ は $30 \mathrm{~mm}$ で一定であった.本リニアモータの磁石列は, $\mathrm{S}$ 極と $\mathrm{N}$ 極の永久磁石が $30 \mathrm{~mm}$ ピッチで交互に配置されているため, リニアモータのコアに働く磁気吸引力がテ 一ブルの移動に伴って周期的に変動し, ピッチングを誘発しているといえる . 


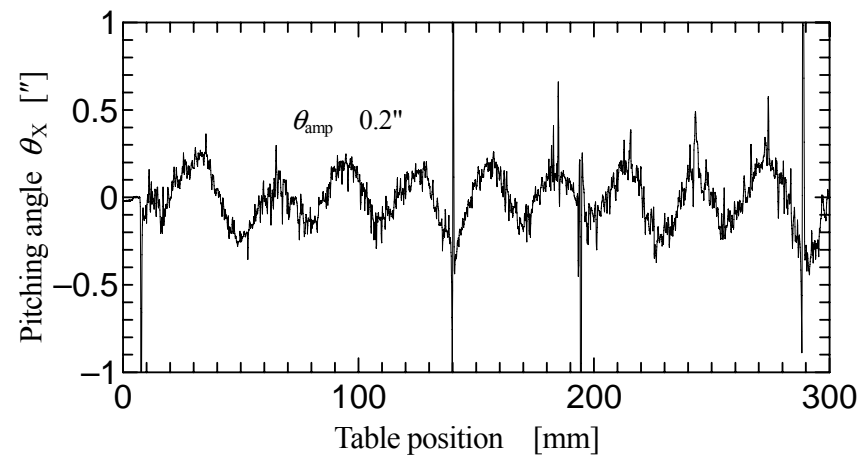

Fig.11 Measured pitching angle of the table $\left(v=1.67 \mathrm{~mm} / \mathrm{s}, Q_{\text {Air }}=0 \mathrm{NmL}\right)$

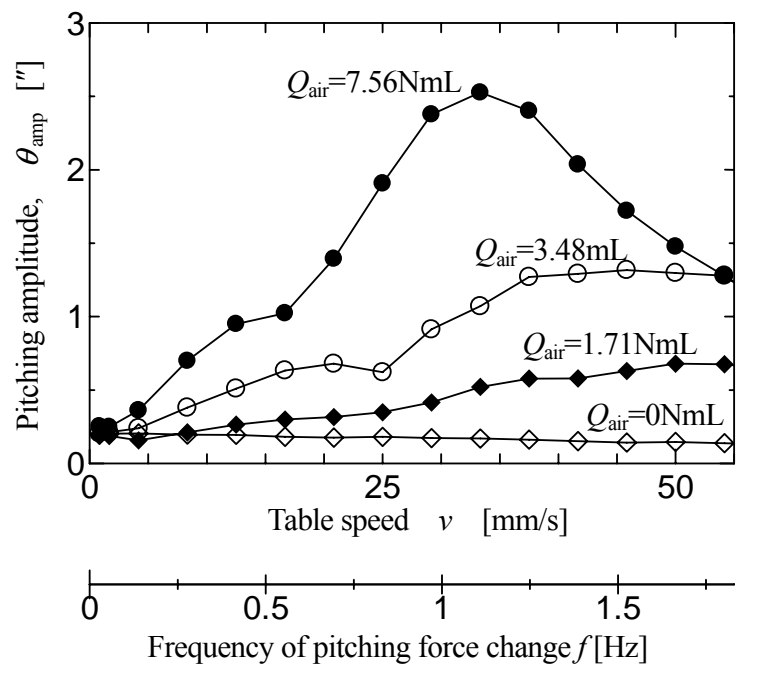

Fig.12 Effect of table speed, $v$, on pitching amplitude, $\theta_{\mathrm{amp}}$

図 12 は, $Q_{\mathrm{Air}}=0,1.71,3.48,7.56 \mathrm{NmL}$ の各条件で, $v$ を 0 55mm/s に変化させた場合における $\theta_{\mathrm{amp}}$ の変化を 示している.配管中の空気か増加するのに伴って， $\theta_{\mathrm{amp}}$ は大きくなる傾向がある . しかし， $Q_{\mathrm{Air}}=7.56 \mathrm{NmL}$ の場合 には, $v=35 \mathrm{~mm} / \mathrm{s}$ 付近で $\theta_{\mathrm{amp}}$ がピークを示しており，ピーク時における加振周波数 $f$ は $(35 \mathrm{~mm} / \mathrm{s}) /(30 \mathrm{~mm}) \fallingdotseq 1.2 \mathrm{~Hz}$

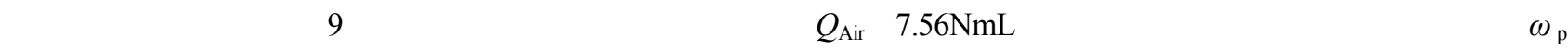
$=1.3 \mathrm{~Hz}$ に近い .このことは,$f$ ごテーブルのピッチングモードの固有振動数に近づくと，振幅か拡大することを 示している.図 12 では, $v=55 \mathrm{~mm} / \mathrm{s}$ までの実験しか行っていないが, さらに送り速度を高くすれば，各々の $Q_{\text {Air }}$ に応じた共振現象か観察できると思われる .

なお $Q_{\mathrm{Air}}=7.56 \mathrm{NmL}$ の場合 , $f=0.42 \mathrm{~Hz}$ 付近でも $\theta_{\mathrm{amp}}$ はわずかにピーク值を示している.これは $f$ ，図 7 より 直線で内挿して推定されるヒービングモードの固有振動数 $\omega_{\mathrm{h}}=0.48 \mathrm{~Hz}$ に近いため, 共振を起こした結果と考え られる . 同樣に $Q_{\mathrm{Air}}=3.48 \mathrm{~mL} / \mathrm{min}$ においても, ヒービングモードで共振している樣子がうかがえる . 本システム では, テーブルの位置にかかわらず, 全磁気吸引力 $F_{\mathrm{m}}$ はほとんど一定であり, かつ理論上, ピッチングモードと ヒービングモードの振動は独立しているはずであるが, 実際には, ピッチングモードの加振力がヒービング振動 を誘発しているものと思われる .なお， $Q_{\mathrm{Air}}=0 \mathrm{NmL}$ の場合においては,$v$ の昇に伴って $\theta_{\mathrm{amp}}$ はやや小さくなる 傾向がある . これは, 水の粘性抵抗のために加振周波数が大きくなるほど , テーブルが振動に追随しにくくなる ためである .

\section{6. 結言}

片側リセス方式の定流量水静圧軸受を備えたリニアモータ駆動テーブルについて , ギアポンプから静圧軸受に 至る配管中に混入した気泡あるいは空気溜りの存在が, テーブルの支持岡性や動特性に及ぼす影響を検討し，以 下の結論を得た .

1) 試作テーブルの中央に載せた荷重 $(980 \mathrm{~N})$ を瞬時に除荷したとき, テーブルのヒービング運動 (垂直変位) は, 配管中に封入した空気の体積 $Q_{\mathrm{Air}}=0 \mathrm{NmL}$ の場合 ,一次遅れ系と同樣の応答を示し , 各定流量ポンプの流 量 $Q=1.0 \mathrm{~mL} / \mathrm{s}$ において $1.4 \mu \mathrm{m}$ の浮き上がりで安定する .つまり 試作テーブルの支持岡性は $700 \mathrm{~N} / \mu \mathrm{m}$ である . この浮き上がり量の $95 \%$ に達するのに要する時間 (時定数 $\tau$ の 3 倍) は約 $0.3 \mathrm{~s}$ であり, 本水静圧テーブルの粘 性減衰係数をもとに試算した值 $(0.33 \mathrm{~s})$ に近い.

2) 上記のヒービング運動は, 配管中への空気の封入によって一変し，二次遅れ系であることを示す減衰振動を行 う.これは，配管中に封入した空気が弱いばねとして作用するためである．例えば， $Q_{\text {Air }}=7.95 \mathrm{NmL}$ の場合， ヒービングモードの固有振動数 $\omega_{\mathrm{h}}$ は $0.47 \mathrm{~Hz}$, 減衰比 $\zeta_{\mathrm{h}}$ は 0.32 程度になる . $Q_{\mathrm{Air}}$ の減少に伴って $\omega_{\mathrm{h}}$ と $\zeta_{\mathrm{h}}$ はと もに増加するものの，空気がわずかでも混入するとテーブルの動的な条件下での支持岡性は著しく低下する． 
3) 空気を封入した状態で, テーブルの一端に載せた $980 \mathrm{~N}$ の荷重を瞬時に除荷すると , テーブルはピッチング運 動を行う. $Q_{\text {Air }}=7.07 \mathrm{NmL}$ の場合 , 最大ピッチング角 $\theta_{\max }$ は $8.53 "$ に達し , ピッチングモードの固有振動数 $\omega_{\mathrm{p}}$ は $1.4 \mathrm{~Hz}$, 減衰比 $\zeta_{\mathrm{p}}$ は 0.35 程度になる. $\theta_{\max }$ は, わずかな気泡の混入で急増することからも , 気泡の混入防止 と混入した空気の排除は極めて重要である.

4) 本テーブルシステムは, 運動の拘束と支持岡性向上のために, コア付きリニアモータの吸引力を利用している ため, テーブルをZ 軸方向に運動させると，永久磁石の配列ピッチに一致した加振力を受け， $Q_{\mathrm{Air}}=0 \mathrm{NmL} の$ 状態でも半振幅 $\theta_{\mathrm{amp}} \fallingdotseq 0.2^{\prime \prime}$ のピッチングが発生する .

5) $\theta_{\mathrm{amp}}$ は, $Q_{\mathrm{Air}}$ と送り速度 $v$ の増加に伴って増加する傾向があり，加振周波数 $f$ がピッチングモードの固有振動 数 $\omega_{\mathrm{p}}$ に近づくと，振幅は急拡大する .

本テーブルシステムは, 超精密平面研削盤への搭載を目指して開発したものであることから， $0.2^{\prime \prime}$ 程度の周期 的なピッチングも加工精度に悪影響を及ぼす . 今後は , テーブルの送り運動に伴うピッチングを抑制する方策に ついて,さらに検討を進める予定である．

\section{文献}

(1) Shimizu S., "The Latest Trends of Machine Tool Development and Their Driving Key Technology", Proc. of the 11th International Machine Tool Engineers Conference (2004), pp.243-253.

(2) United nations, "Kyoto protocol to the United Nations framework convention on climate change" (1998), pp.1-20.

（3）特許庁 標準技術集," 半導体製造装置関連真空口クリーン化技術”， http://www.jpo.go.jp/shiryou/s_sonota/hyoujun_gijutsu/semicon_vacuum_tech/mokuji.htm（参照日2013 年 8 月 14 日）.

（4）加藤重雄,“長方形静圧空気スラスト軸受の最適設計”，精密機械，Vol.47, No.5 (1981), pp.596-601 .

（5）田中克彦, 勝木雅秀,“超精密回転テーブルの構造, 精度と評価方法”, 日本機械学会, 第1 回生産加工・工作機械 部門講演会講演論文集 (1999), pp.167-168.

（6）鈴木秀幸, 浦野好市, 久米原宏之, 楠本一臣 “静圧作動油に起因する超精密工作機械の熱変形抑制”, 精密工学会 誌, Vol.75, No.9 (2009), pp.1106-1111 .

（7）由井明紀, 鈴木祥司，小此木弘孝,三井公之“, 静圧案内を用いた超精密平面研削盤の開発，”砥粒加工学会誌, Vol.41, No.10 (1997), pp.376-381 .

（8）長島 碧 , 中尾陽一 “水静圧軸受における軸受隙間や軸受絞りの誤差の影響”，日本機械学会 2009 年度年次大会講 演論文集, Vol.4 (2009), pp.17-18 .

（9）磯部 章, 富田良幸, 岩瀬昭雄, “ 脆性材料の機械加工技術 - 付加価値の高い電子材料の加工 - シリコンウエハ工程 別加工技術 両頭研肖l”，機械と工具, Vol.44, No.5 (2000), pp.50-53.

(10) 奥山繁樹 , 由井明紀 , 熊谷誠弥 , 北嶋孝之 “ リニアモータ駆動加水静圧案内テーブルの開発 (定流量静圧軸受の基 本設計)”，日本機械学会論文集 C 編，Vol.75, No.750 (2009), pp.454-459.

(11) 由井明紀, 熊谷誠弥, 北嶋孝之, 奥山繁樹, 藤田悦男, A.H. Slocum “ リニアモータ駆動加水静圧案内テーブルの 開発 (テーブルシステムの設計開発と静的特性)”，日本機械学会論文集 C 編，Vol.75, No.752 (2009), pp.1128-1134.

(12) 中川孝之, 大住 剛,“混入空気を考慮した油圧作動油の体積弾性係数について”, 富山大学紀要，Vol.27 (1976), pp.25-30.

(13) 東京計器技術資料, http://www.tokyo-keiki.co.jp/hyd/j/products/pdf/z_001.pdf（参照日 2013 年 8 月 14 日）. 